OPEN ACCESS

Edited by:

Zhi-jun Dai,

East China Normal University, China

Reviewed by:

Shenliang Chen,

East China Normal University, China

Mei Xuefei,

East China Normal University, China

*Correspondence:

Qing Wang

schingwang@126.com

Xianbin Liu

liuxb@/du.edu.cn

these authors share first authorship

Specialty section: This article was submitted to Coastal Ocean Processes, a section of the journa Frontiers in Marine Science

Received: 19 August 2021 Accepted: 22 September 2021 Published: 22 October 2021

Citation:

Zeng L, Zhan C, Wang Q, Liu X, Wang L, Li X, Wang $X$, Y $X$ X, Zhang J and Cui $B$ (2021) Sediment Coarsening in Tidal Flats and Stable Coastline of the Abandoned Southern Yellow River Sub-Delta in Response to Fluvial Sediment Flux Decrease

During the Past Decades.

Front. Mar. Sci. 8:761368. doi: 10.3389/fmars.2021.761368

\section{Sediment Coarsening in Tidal Flats and Stable Coastline of the Abandoned Southern Yellow River Sub-Delta in Response to Fluvial Sediment Flux Decrease During the Past Decades}

\author{
Lin Zengt, Chao Zhant, Qing Wang*, Xianbin Liu*, Longsheng Wang, Xueyan Li, \\ Xin Wang, Xiang Yu, Jinzhi Zhang and Buli Cui
}

Institute of Coastal Research, Ludong University, Yantai, China

Due to remarkable reduction of sediment supply, the vulnerability of Yellow River deltaic system increased and ecological impacts occurred to some extent. To have a comprehensive and quantitative understanding of the morphological evolution of deltas, surficial sediments of tidal flat along the abandoned southern Yellow River sub-delta and two adjacent coastal units were systematically collected and evaluated by grainsize analysis in the study. The results reveal that surficial sediments of the abandoned southern Yellow River sub-delta have been coarsening significantly since the 1980s, as characterized by a decrease in both the mud content and the clay/mud ratio. In particular, the transition from cohesive to non-cohesive sediment was completed between 2007 and 2013. With a sharp decrease in sediment flux from the Yellow River estuary, the flood currents from the submarine coastal slope carry few fine particles into the tidal zone, whereas the ebb currents with reverse direction remove some fine particles from the tidal flat. This is a major cause of sediment coarsening in the tidal flat. As sediment coarsening, the coastline of the abandoned southern Yellow River subdelta has remained stable. The significant change in the grain size of the tidal flat surficial sediments may have a profound impact on the future coastal geomorphic evolution.

Keywords: coarsening tendency, Yellow River delta, abandoned sub-delta, tidal flat, surficial sediment, grain size

\section{INTRODUCTION}

Mega-deltas around the world, such as the Nile River, Mississippi River, Yangtze river, and Yellow River, has been under the threat of erosion and retreat, due to remarkable reduction of sediment supply as a function of climatic change and human activity (Stanley and Warne, 1993; Blum and Roberts, 2009; Yang Z. S. et al., 2011; Li et al., 2017; Jiang et al., 2018). Consequently, the vulnerability of deltaic system increased and ecological impacts occurred to some 
extent (Giosan et al., 2014). So, to maintain or restore deltaic sustainability, a comprehensive and quantitative understanding of the morphological evolution of deltas is urgently needed.

As with other rivers in the world, the sediment flux from the Yellow River into the Bohai Sea has decreased significantly since the 1950s caused by construction of a series of dams (Wang et al., 2007, 2011; Yu et al., 2013). Many studies have been carried out on the response of the Yellow River delta to the decrease in sediment flux, especially the impact of coastal morphodynamics (Li et al., 1998a,b, 2000; Qiao et al., 2008, 2011; Yang S. L. et al., 2011; Jiang et al., 2017, 2018), coastal erosion/accretion and coastline changes (Chu et al., 2006; Ma and Li, 2010; Cui and Li, 2011; Liu et al., 2013; Bi et al., 2014), and the retreat of the abandoned northern sub-delta (Wang et al., 2006).

Tidal flats are the critical zone of coasts where direct interaction occurs between the sea and the land. The grain-size variation of tidal flat surficial sediments can reflect information of subtle changes in the hydrodynamics (Folk and Ward, 1957; Kenyon and Stride, 1970; Johnson et al., 1980; Flemming, 1988; Anthony and Héquette, 2007; Bartholomä and Flemming, 2007; Anthony et al., 2010). Therefore, many studies focus on the depositional characteristics and geomorphic evolution of tidal flats together with their response to the changes of natural environment and recent human activity (Eisma, 1998; Chang et al., 2007; Law et al., 2013; Clarke et al., 2014; Rahman and Plater, 2014; Gensac et al., 2015; Jongepier et al., 2015; Zhou et al., 2015). However, specific research on the grain-size characteristics of surficial sediment and trends of morphodynamic evolution of tidal flats in the Yellow River delta is scarce, especially in the context of a decrease in sediment flux.

The aim of this study is to: (1) characterize the spatial distribution and evolution of the grain-size composition of tidal flats sediments in the Yellow River delta; (2) reveal the possible relation between sediment flux changes of Yellow River and grain-size characteristics of tidal flats sediments; (3) clarify the morphodynamic mechanisms for coastline stability in the abandoned southern Yellow River sub-delta.

\section{STUDY REGION}

The modern Yellow River delta has developed since the Yellow River began to pour into the Bohai Sea again in 1855. Since then, the Yellow River estuary has migrated north or southward more than 18 times along the coast of Bohai Sea. Consequently, a new river mouth sandspit and sub-delta formed rapidly, and the abandoned sub-delta retreated synchronously in response to estuary migration (Guo, 1980). As a result, the Yellow River delta, which is composed of many sub-deltas, has extended into the Bohai Sea continually. Among these sub-deltas, the present Yellow River sub-delta (PYS) is shaped by the Qingshuigou channel estuary of the Yellow River (Figure 1). The abandoned southern Yellow River sub-delta (ASYS) is located between the PYS and the alluvial plain of the southern Laizhou Bay (PSLB), and mainly developed during the periods of 1934-1938 and 1947-1953 when the Yellow River flowed into the Bohai Sea along the Tianshuigou channel.

\section{METHODOLOGY}

Surficial sediment samples were collected using a homemade sampler $(15 \mathrm{~cm} \times 15 \mathrm{~cm} \times 0.5 \mathrm{~cm})$ along the tidal flats of the whole ASYS and adjacent zones like PYS and PSLB during neap tides between March 2013 and July 2014 (Figure 1). In total, 238 samples were collected, among which 72 samples (Nos. 1-72) in the PSLB, 122 samples (Nos. 73-194) in the ASYS, and 44 samples (Nos. 195-238) in the PYS (Figure 1). Among 238 samples, 106 sample points were arranged along 10 tidal flat transverse profiles, of which eight profiles were located in the ASYS and the other two were located in the PSLB (Figure 1).

To gain a long-term perspective of the hydrodynamics and understand the real evolutionary trends of the delta system, all published data about the sand-silt-clay composition of tidal flat surficial sediment samples along the ASYS and adjacent regions were collected. The data includes: two samples that were collected from the Beihaipu coast that was part of the ASYS in 1989 ( $\mathrm{Li}$ et al., 1991), 17 samples that were taken from along the coast that is part of the ASYS and PYS between the Zimaigou river estuary and the Qingshuigou channel estuary in 2006 (Xing, 2007), and 20 samples taken from the coast that is part of the ASYS between the Zimaigou River estuary and the Laohekou (Tianshuigou channel estuary) in 2007 (Liu et al., 2010; Chen and Huang, 2014).

The grain-size distribution of the sediments was analyzed using a Malvern Mastersizer 2000 laser particle-size analyzer with a measurement range of $0.02-2000 \mu \mathrm{m}$ and a relative error of $2 \%$. The pre-treatment procedure consisted of the removal of organic matter and secondary carbonates by the addition of $10 \%$ $\mathrm{H}_{2} \mathrm{O}_{2}$ and $10 \% \mathrm{HCl}$, respectively, followed by dispersal using $10 \mathrm{ml}$ of $0.05 \mathrm{~mol} / \mathrm{L}\left(\mathrm{NaPO}_{3}\right)_{6}$ and treatment in an ultrasonic vibrator for $10 \mathrm{~min}$. Grain-size statistics were calculated using the GRADISTAT (v8.0) program developed by Blott and Pye (2001). The Udden - Wentworth grade scale (Udden, 1914; Wentworth, 1922) was adopted as the grain-size scale, where the grade scale boundaries are logarithmically transformed to phi $(\Phi)$ values, using the expression $\Phi=\log _{2} d$ ( $d$ is the grain diameter in $\mathrm{mm}$ ).

The grain size parameters of mean grain size $(\mathrm{Mz})$, sorting coefficient (So), skewness (SK), and kurtosis (KG) were obtained via the Folk and Ward (1957) graphical method. According to Sahu (1964), the mean grain size signifies the average kinetic energy of the inter-tidal flats with a positive relationship. The sorting coefficient signifies the kinetic energy fluctuations of the depositing environment with an inverse relationship between the coefficient and the sorting degree (Sahu, 1964). Skewness marks the position of the mean with respect to the median grain size. A positive skew implys fine grain loss and coarse grain enrichment, relatively (Sahu, 1964). As a non-environmentsensitive grain size parameter (Friedman, 1961), Kurtosis reflects the source diversity of the inter-tidal flat. The high values imply that proximal debris from the adjacent environment enters and is deposited directly in the inter-tidal flat without long distance transportation. According to Collins (1987) and Mazzullo et al. (1988), higher mud content signifies stronger hydrodynamics in the inter-tidal flat, and vice versa. According 


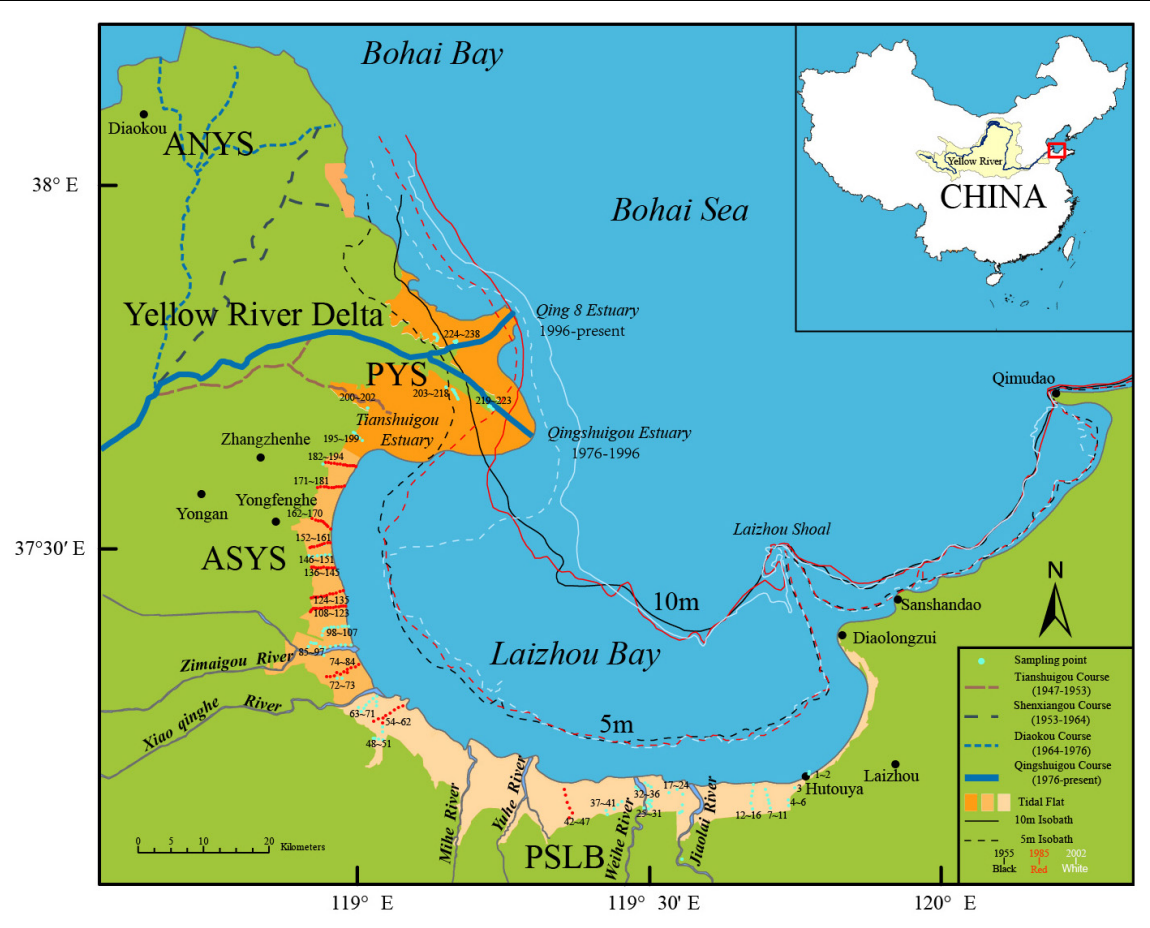

FIGURE 1 | Location of the abandoned southern Yellow River sub-delta (ASYS) and its adjacent zones (ANYS, PYS, and PSLB). Coastal topography evolution is drawn with the help of GIS based on nautical charts measured in 1955, 1985, and 2002. Sampling locations of tidal flat surficial sediment samples are arranged clockwise one after another from land to sea. The sample points making up 10 tidal flat transverse profiles are shown by red solid circles.

to Ergin and Bodur (1999), higher clay contents and clay/mud ratio reflect weaker hydrodynamics in the inter-tidal flat, and vice versa. Thus, the clay/mud ratio should be a good indicator of hydrodynamics in the silt muddy tidal flat around YRD.

\section{RESULTS}

\section{Sand-Silt-Clay Content and Mean Grain Size}

For the three coastal segments in detail, the mean values (and ranges) of sand, silt, and clay contents of the samples, respectively, are: $35.6 \%(1.9-83.9 \%), 60.5 \%(14.0-89.7 \%)$, and $3.9 \%(0-9.9 \%)$ for the ASYS; and those from the PYS are $10.6 \%$ (1.1-30.2\%), 82.1\% (7.9-94.2\%), and 7.4\% (11.9-4.6\%); those from the PSLB are 68\% (29.3-90.9\%), 29.6\% (7.9-65.5\%), and 2.5 (0-5.9\%). Generally, the sand, silt, clay contents of the tidal flat samples of the ASYS are significantly different from those of the PYS and PSLB (Figure 2).

The mean values (and ranges) of the mean grain size of the ASYS, PYS, and PSLB are $4.4(2.8-6.0) \Phi, 5.5$ (4.9-6.1) $\Phi$, and 3.7 (1.7-4.9) $\Phi$, respectively (Figure 2). To be specific, the number of samples from the ASYS (total of 122) with mean grain size less than $3 \Phi$ (fine sand) is only 1 (less than $1 \%$ ), 3-4 $\Phi$ (very fine sand) is $14(11 \%), 4-6 \Phi$ (silt) is $106(87 \%)$, and larger than $6 \Phi$ (clay) is only 1 (less than $1 \%$ ). The total number of samples from the PYS (44) with a mean grain size between 4 and $6 \Phi$ (silt) is 43 (98\%) and only 1 sample (2\%) has a mean grain size larger than
$6 \Phi$ (clay). The samples from PSLB (72) with a mean grain size less than $3 \Phi$ (medium sand and fine sand) is 2 (3\%), 3-4 $\Phi$ (very fine sand) is 55 (76\%), 4-6 $\Phi$ (silt) is $15(21 \%)$, and larger than 6 $\Phi$ (clay) is only 1 (approximately $1 \%$ ).

\section{Granularity Distribution Along Transverse Profiles}

Two of 10 studied inter-tidal flat transverse profiles are located in PSLB and 8 are in ASYS (Figure 1). As shown by the grainsize composition curves of the 10 transverse profiles, the tidal flat becomes markedly coarser from land to sea. The mean grain size and the sand content increase significantly and the silt, clay, and mud (the sum of silt and clay) contents decrease (Figure 3).

\section{DISCUSSION}

\section{Sediment Coarsening in Tidal Flats}

According to the published grain size data, the surficial sediment of the high tidal flat in Zhangzhenhe and Yongfenghe, located in the middle of the ASYS coast, was mainly composed of clayey silt with a clay content of $20-40 \%$, and the low tidal flat was mainly composed of silt with a clay content of 15-20\% in 1983 (Liu et al., 1985). Around the same period, the clay content of the high tidal flat surficial sediment from Beihaipu in 1989 was $39.8 \%$, and that of the middle tidal flat was $16.5 \%$ (Li et al., 1991). As illustrated in Figure 4, according to the grain size data of the 17 tidal flat surficial sediment samples from the Zimaigou estuary 


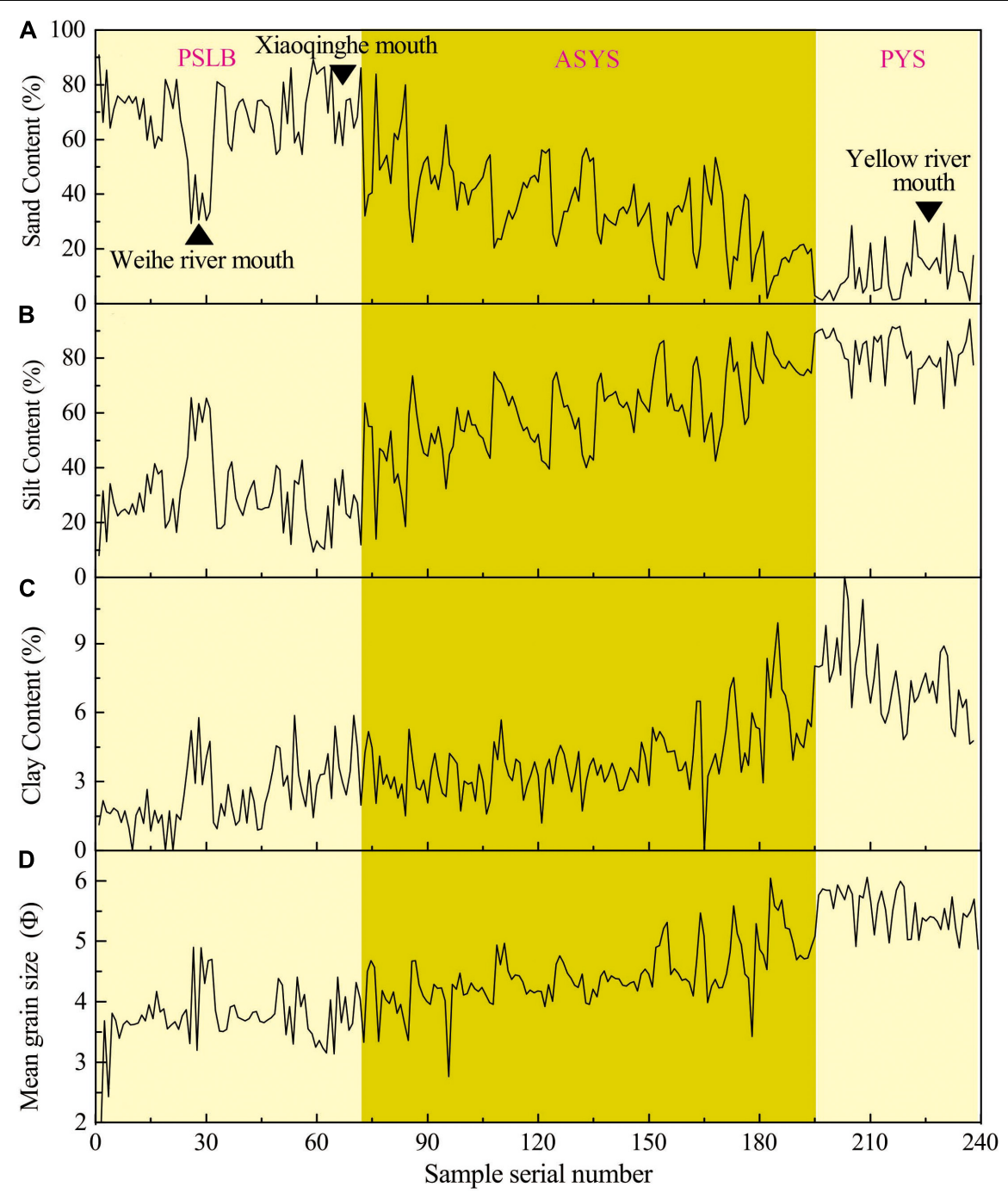

FIGURE 2 | The change curves of sand content (A), silt content (B), clay content (C) and mean grain size (D) of tidal flat surficial sediments from ASYS and adjacent zones.

to the Yellow River estuary taken in 2006, the clay content was 5.7-29.5\% and the mean content was only $14.0 \%$ (Xing, 2007). These results above show that there was no significant variation in the clay content of the surficial sediments of the tidal flat along the ASYS coast in the 1980s. However, we can speculate that the clay content will have undergone significant change after the1980s and dropped considerably, no later than 2006.

The tidal flat surficial sediment dataset of 2006-2007 plotted in a ternary diagram is distributed with a similar shape to that of the 2013-2014 dataset, with a straight band toward the siltclay axis, encompassing several textural classes from sand to clay (Figure 4). However, the location of the dataset with the highest clay/mud ratios (of more than 10\%) deviates clearly from the silt endmember and approaches the clay endmember, which differs from the character of the 2013-2014 dataset. Meanwhile, the distribution range changes little toward the silt-clay axis, without an obvious narrowing tendency. The clay/mud ratios of the 17 samples from the Zimaigou estuary to the Yellow River estuary range from 11.5 to $33.0 \%$ with a mean value of $19.0 \%$. Thus, it can be concluded that the surficial tidal flats continued to coarsen from 2007 to 2013.

According to Dyer (1986), Van Ledden et al. (2004), and Law et al. (2008), the transition from non-cohesive to cohesive sediment occurs when clay content exceeds a threshold of 5-10\%. This is because the erodibility of the sediment decreases when the clay content increases to exceed this threshold, as does sorting during erosion (Dyer, 1986; Van Ledden et al., 2004). Thus, small changes of clay content in surficial deposits can have a significant influence on the erosion/sedimentation and the sorting in tidal flats. The mean clay content of the 17 samples was $14.1 \%$ along the tidal flats from the Zimaigou estuary to the Yellow River estuary in 2006. The clay contents of only two samples were less than $10 \%$ (Xing, 2007). However, along the same coast, the clay contents of only three samples were more than $10 \%$ 


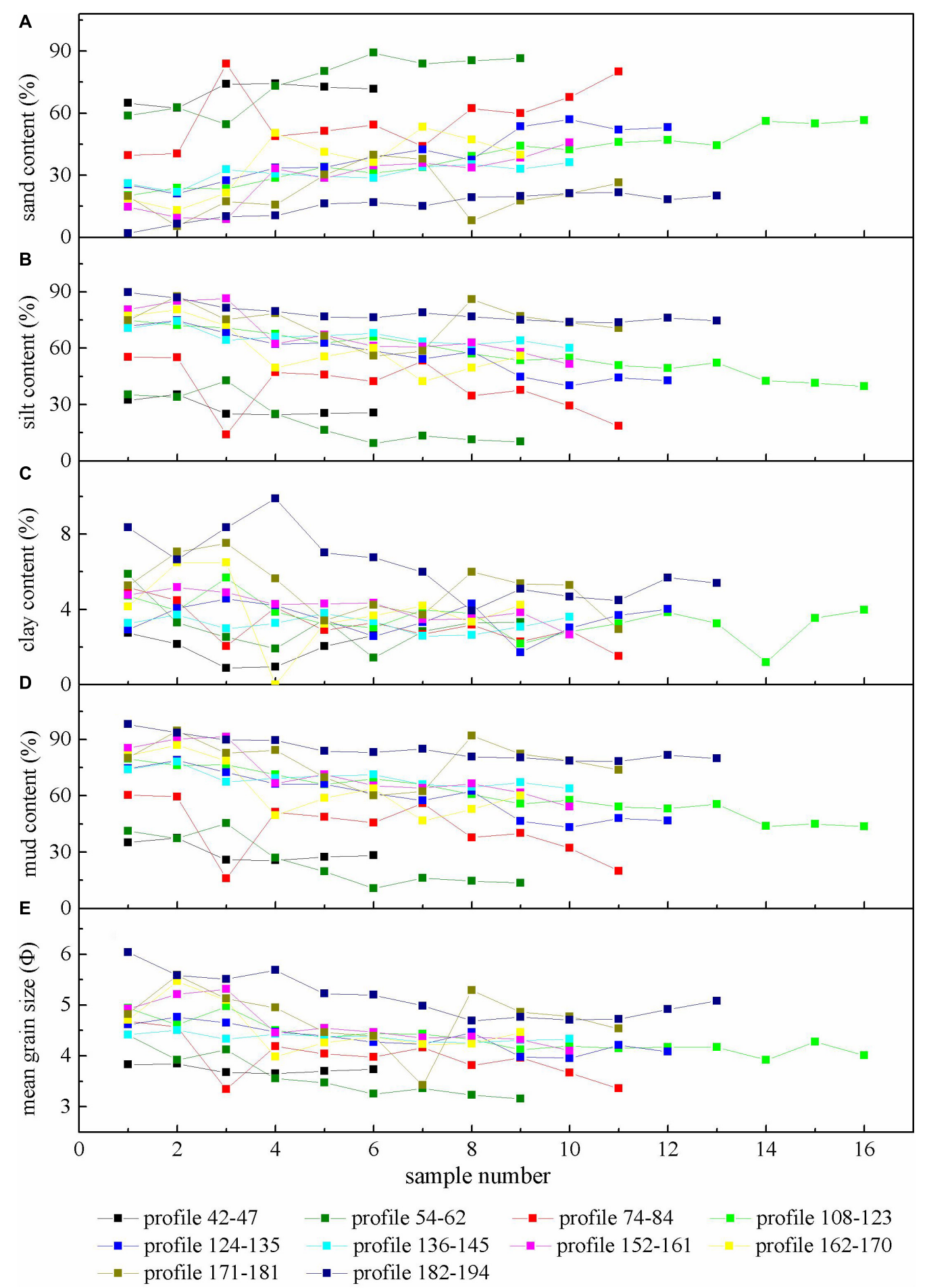

FIGURE 3 | The profile change curves of sand content (A), silt content (B), clay content (C), mud content (D) and mean grain size (E) of tidal flat surficial sediments from the ASYS and adjacent zones.

among the 152 samples in 2014 with a maximum of $11.9 \%$. The results revealed that the significant coarsening from 2007 to 2013 achieved the transition from cohesive to non-cohesive surficial sediment in the tidal flat.
The water depth on the seafloor east of the ASYS changed from 0 to $5 \mathrm{~m}$ and its surficial sediment also had coarsened significantly from 1980 to 1997 (Liu and Yan, 1998). The water depth of the seafloor east of the northern ASYS ranged from 2 to $10 \mathrm{~m}$ prior to 


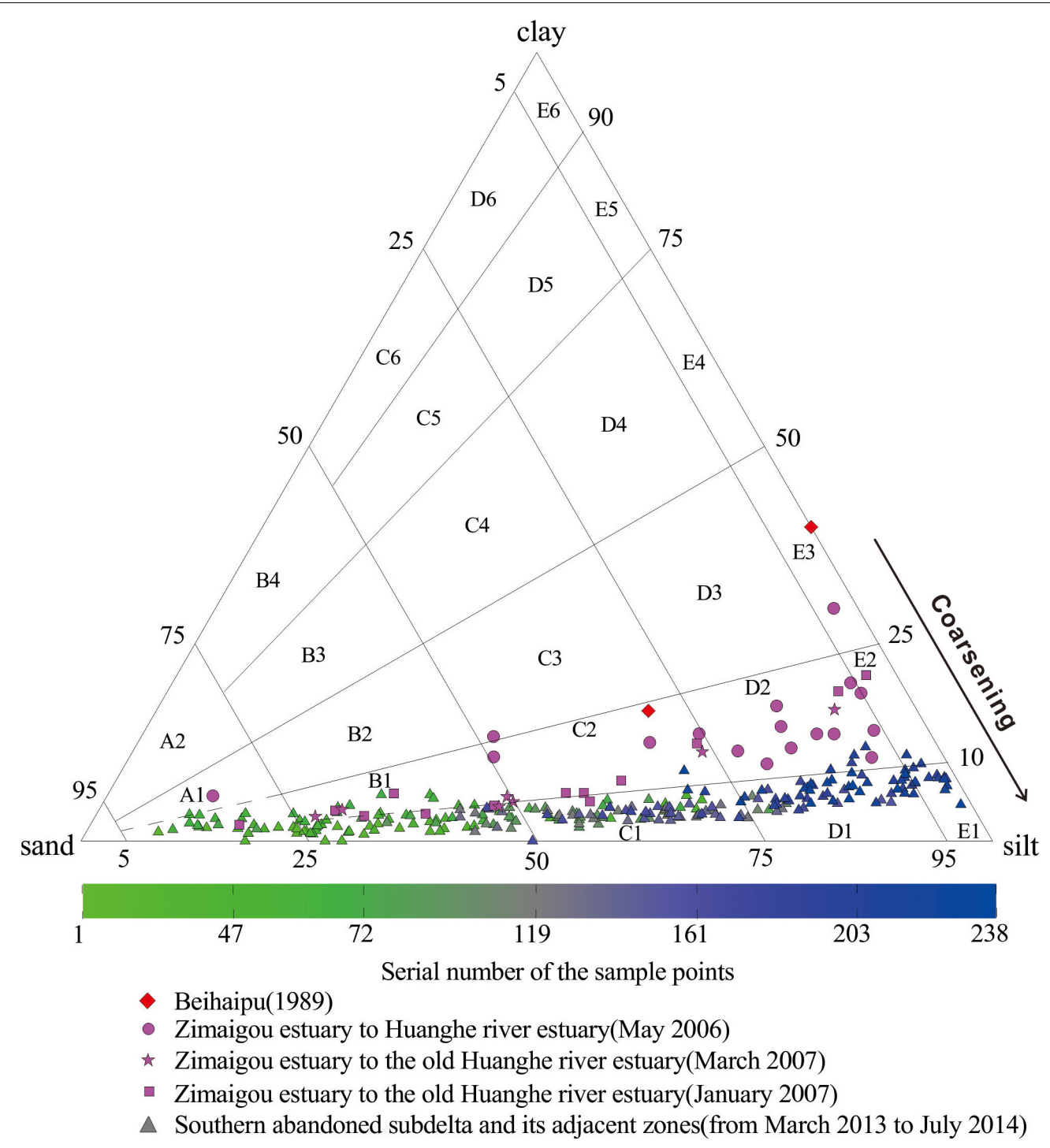

FIGURE 4 | Ternary diagrams based on sand/silt/clay ratios illustrating textural trends observed in the tidal flats of the southern abandoned sub-delta of the Yellow River and adjacent zones. The grain-size composition data from Beihaipu and the zones from the Zimaigou estuary to the Yellow River estuary are collected from Li et al. (1991), Xing (2007), Liu et al. (2010), and Chen and Huang (2014).

the 1980s. There existed a "mire," which was a region covered by rapidly deposited silty clay with its surficial sediment because the fluid mud was apt to be re-suspended under the action of waves (Pang and Si, 1980; Liu and Gao, 1986; Wu, 1992). However, the silty clay region corresponding to the so-called "mire" in 1999 had shrunk sharply compared to that in 1985 (Lv and Li, 2004). Thus, both the surficial tidal flat and seafloor sediments near the ASYS have been coarsening significantly in the last 30 years.

\section{Mechanisms of Sediment Coarsening of Tidal Flat of Abandoned Southern Yellow River Sub-Delta}

The main reasons for surficial sediment coarsening of tidal flat include hydrodynamic enhancement and the change of sediment source. Based on hydrodynamic model proposed by Pejrup (1988), the location of a dataset in a ternary diagram reflects the specific hydrodynamic conditions of the sedimentary environment, with coarser sediment representing more energetic conditions. The hydrodynamics of Laizhou Bay had weakened before 1996 because of the increasingly enclosed bay mouth that resulted from the eastward extension of the PYS sandspit; it has tended toward stability since1996 and the formation of the Qing 8 channel (Figure 1). Thus, hydrodynamic enhancement cannot be the main reason for the tidal flat sediment coarsening and the sediment coarsening is more likely to be the result of the sharp decrease in sediment load from the Yellow River.

According to previous studies (Collins, 1987; Mazzullo et al., 1988; Ergin and Bodur, 1999), the mud contents and the clay/mud ratios of tidal flat sediments can jointly reflect the 
change of hydrodynamic intensity, and the relationship between them should be inversely proportiona. However, there does not appear to be a significant relevant relation between the mud contents and the clay/mud ratios for the ASYS and its adjacent zones (Figure 5), implying that the erosion-accretion factors controlling silt and clay contents of the tidal flat surficial sediments are different.

The sorting coefficients of samples along the ASYS and PSLB increase as mean grain size increases (Figure 6A), indicating that the sorting of finer sediment is poorer and the sorting of coarser sediment is better. However, this relation between sorting coefficient and mean grain size does not exist in the PYS (Figure 6A), which implies that the sediment is derived mainly from in situ sedimentation of suspended clastic material in the Yellow River without long-distance hydrodynamic sorting. The skewness of the PYS is negatively correlated with the mean grain size (Figure 6B), which implies that coarser sediment of inter-tidal flats corresponds to a higher accumulation degree of

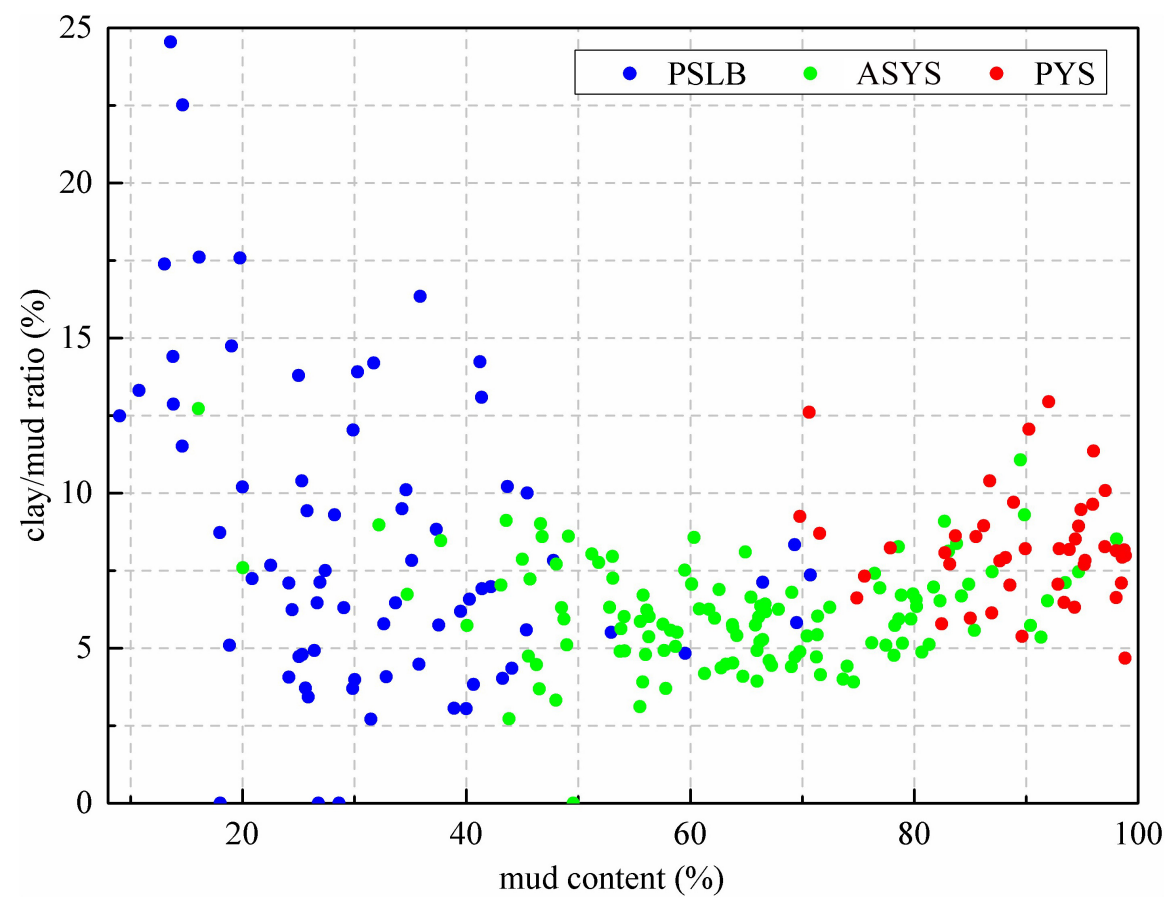

FIGURE $\mathbf{5}$ | The bivariate plot between the mud content and clay/mud ratio of the tidal flat surficial sediments along the southern abandoned Yellow River sub-delta and adjacent zones.
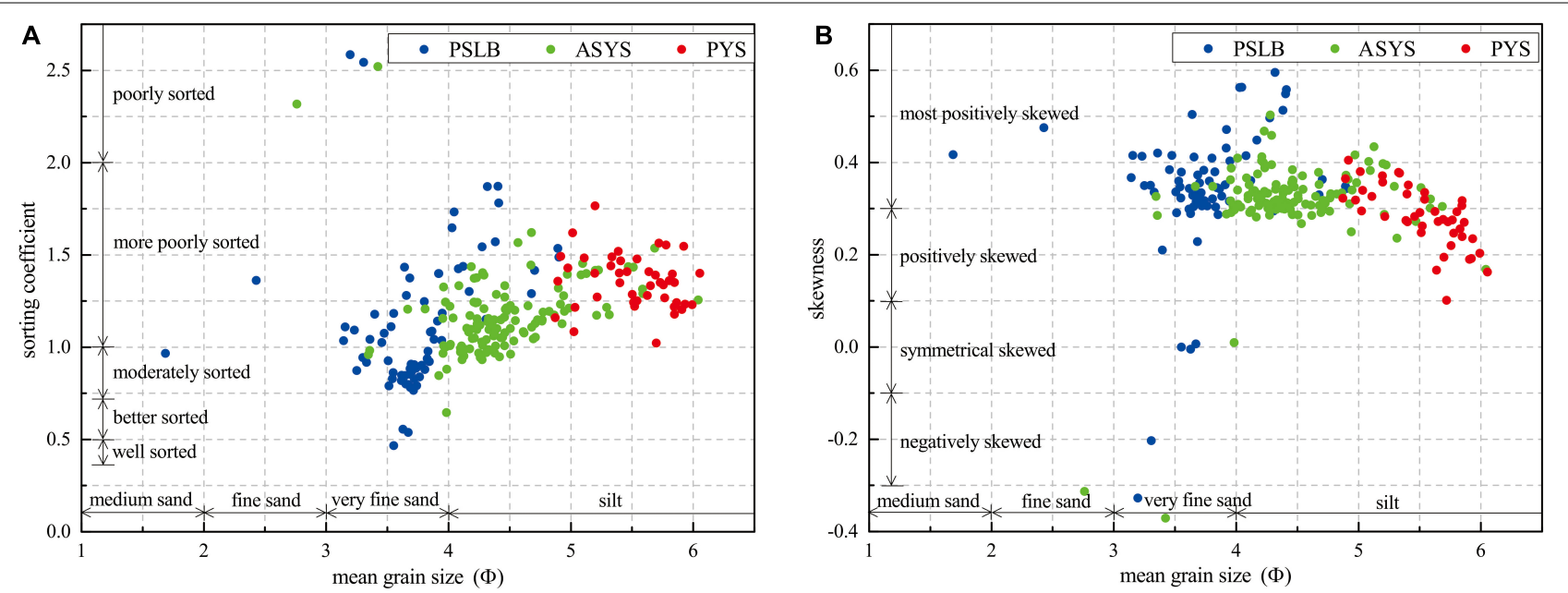

FIGURE 6 | The bivariate plot of sorting coefficient versus mean grain size (A) and skewness versus mean grain size (B) of the tidal flat surficial sediments of the southern abandoned sub-delta and adjacent zones. 
coarse particles. However, this correlation between skewness and mean grain size does not exist for the ASYS and PSLB coasts (Figure 6B), which signifies that the accumulation of coarse particles in the tidal flats is independent of sediment grain size.

Tidal flats are not isolated morphodynamic units in the coastal zone. There must have been some influences to support the phenomenon of tidal flat sediment coarsening, such as the local coarsening of seafloor sediments (Eisma, 1998). After the construction of a large number of reservoirs in the upper and middle reaches of the Yellow River, the sediment runoff into the Yellow River estuary decreased greatly. The grain size of tidal flat of the ASYS changes little along coast and significantly different from that of PYS and PSLB, so the ASYS has almost no longitudinal sediment exchange with its adjacent coastal sediments (Figures 2, 5, 6). Because of the abrupt reduction in sediment, the flood currents from the submarine coastal slope carry few fine particles into the tidal zone, whereas the ebb currents with reverse direction remove some fine particles from the tidal flat. This is a major cause of sediment coarsening in the tidal flat and the decrease in clay content and clay/mud ratio.

\section{Stable Coastline of Abandoned Southern Yellow River Sub-Delta and Its Future Geomorphic Evolution}

In contrast to the tidal flat surficial sediment coarsening from land toward the sea (Figure 3), the surficial sediment of the seafloor shallower than $2 \mathrm{~m}$ outside both the ASYS and PSLB becomes increasingly coarse from sea toward the land. Grain-size analysis results from 207 surficial sediment samples collected in 2007 from below the $5 \mathrm{~m}$ isobath east of the ASYS (Zhang et al., 2014) show that sand accounts for less than $10 \%$, silt from more than $70 \%$, and clay for more than $20 \%$ of the total deposited sediment. The sand content increases, but silt and clay contents decrease significantly, from the 5 to $2 \mathrm{~m}$ isobaths. Therefore, a narrow zone of coarse particles parallel to the coastline, with the characteristics of high sand and low mud content, develops between the outer edge of the tidal zone and the $2 \mathrm{~m}$ isobath. After the sub-delta of ASYS was abandoned, the sediment source disappeared, resulting in a relatively enhanced geomorphic effect of waves, and a relatively weakening of the geomorphic effect of tidal currents. Part of the clay components in the original tidal flat deposits were also transported away from the intertidal zone, so the sediments of tidal flats eventually became coarse.

As sediment coarsening caused by transverse sediment exchange between tidal flat and the submarine slope, the morphology of ASYS coast has remained relatively stable in recent decades compared to rapidly retreat in the ANYS (Figure 7). During the 50-year period from 1959 to 2009, although the shoreline of ASYS has advanced and retreated, but the magnitude and rate of change are more than an order of magnitude lower than that of other sub-deltas in YRD. During the period from 2002 to 2009, the shoreline of ASYS retreats relatively obviously than before, which may be related to the rapid erosion and retreat of the Qingshuigou sand spit after 1996, which led to a weakening of its barrier function and ultimately an increase in the direct wave action.

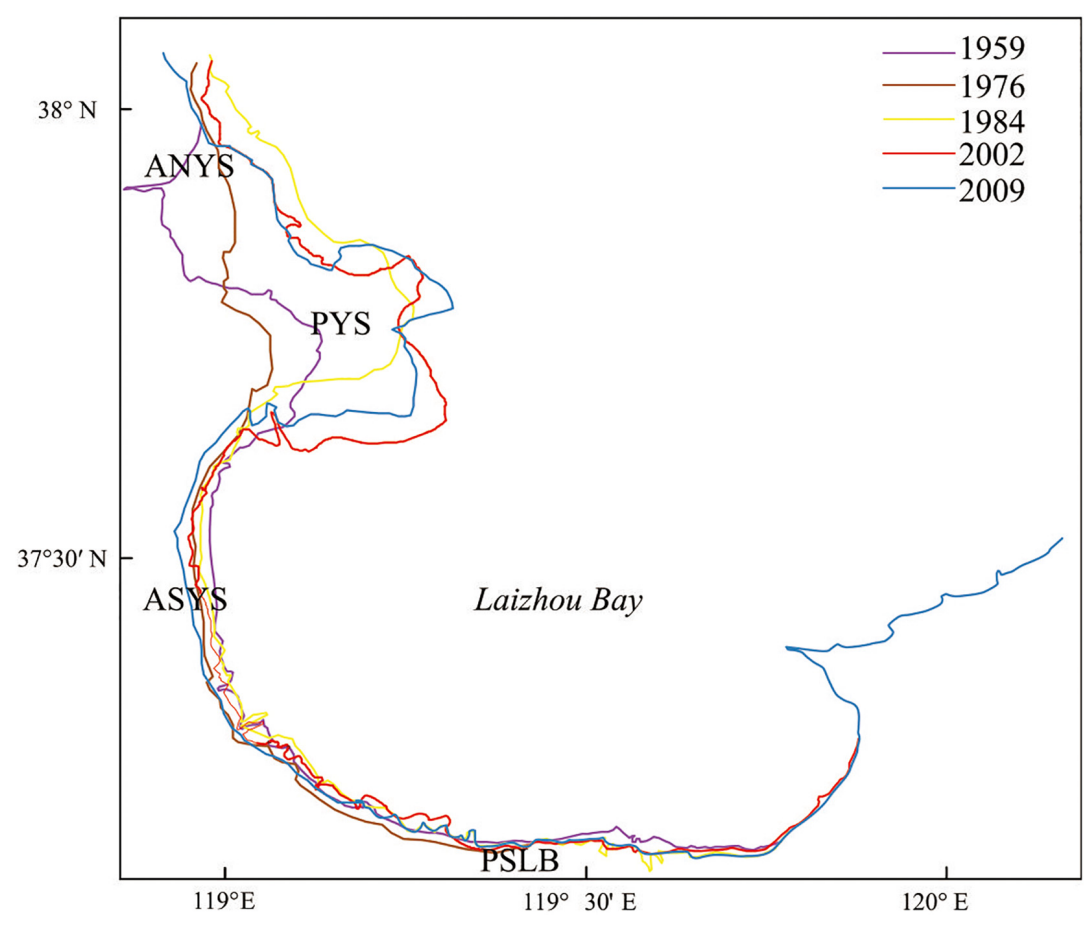

FIGURE 7| The coastline evolution of the southern abandoned sub-delta and adjacent zones. The figure is drawn with the help of GIS tools based on nautical charts measured in 1959, 1976, 1984, 2002, and 2009. 
According to historical and geological records, the Yellow River delta has repeatedly been subject to the alternation of both sandy and muddy coasts and the marine transgression and regression with time scales of centuries and millennia over the last 2500 years (Chen, 1980; Chen, 1982; Saito et al., 2000). On a short time scale, many researchers have shown that the abandoned northern Yellow River sub-deltas retreated rapidly because of the river estuary migration and disappearance of sediment supply in recent decades (Guo, 1980; Wang et al., 2006). However, even under the background of the significant reduction of sediment into the sea of the Yellow River in recent decades, the coastline of ASYS has not retreated significantly. Thus, we conclude that marine sediments from the Laizhou Bay give a substantial contribution to the maintenance of tidal flats and that there can be a long-time lag between coastal erosion and the deltas response to the decline in sediment supply, as the study of the Yangtze River Delta shows (Dai et al., 2018; Wei et al., 2018; Leonardi et al., 2021). Understanding the geomorphic response to sediment change is not only relevant to the relationship between surficial tidal flat sedimentation and a decrease in sediment flux, it may contribute to the understanding of morphodynamic development along muddy coasts around the world.

\section{CONCLUSION}

The Yellow River delta has been under the threat of erosion and retreat, due to remarkable reduction of sediment supply since the 1950s. In the study, surficial sediments of tidal flat along the abandoned southern Yellow River sub-delta and two adjacent coastal units were systematically collected and evaluated by grainsize analysis in order to have a comprehensive understanding of the morphological evolution of Yellow River delta.

The surficial sediment characteristics of tidal flats along the ASYS are significantly different from those of the PYS located in the north together with the PSLB located to the south. With a

\section{REFERENCES}

Anthony, E. J., Gardel, A., Gratiot, N., Proisy, C., Allison, M. A., Dolique, F., et al. (2010). The Amazon-influenced muddy coast of South America: a review of mud-bank-shoreline interactions. Earth Sci. Rev. 103, 99-121. doi: 10.1016/j. earscirev.2010.09.008

Anthony, E. J., and Héquette, A. (2007). The grain size characteristation of coastal sand from the somme estuary to Belgium: sediment sorting processes and mixing in a tide- and storm-dominated setting. Sediment. Geol. 202, 369-382. doi: 10.1016/j.sedgeo.2007.03.022

Bartholomä, A., and Flemming, B. W. (2007). Progressive grain size sorting along an intertidal energy gradient. Sediment. Geol. 202, 464-472. doi: 10.1016/j. sedgeo.2007.03.010

Bi, N. S., Wang, H. J., and Yang, Z. S. (2014). Recent changes in the erosionaccretion patterns of the active Yellow (Yellow River) delta lobe caused by human activities. Cont. Shelf Res. 90, 70-78. doi: 10.1016/j.csr.2014.02.014

Blott, S. J., and Pye, K. (2001). GRADISTAT: a grain size distribution and statistics package for the analysis of unconsolidated sediments. Earth Surf. Proc. Land. 26, 1237-1248. doi: 10.1002/esp.261

Blum, M. D., and Roberts, H. H. (2009). Drowning of the Mississippi Delta due to insufficient sediment supply and global sea-level rise. Nat. Geosci. 2, 488-491. doi: 10.1038/ngeo553 sharp decrease in sediment flux from the Yellow River estuary, the flood currents from the submarine coastal slope carry few fine particles into the tidal zone, whereas the ebb currents with reverse direction remove some fine particles from the tidal flat. This is a major cause of sediment coarsening in the tidal flat since the 1980s. In particular, the transition from cohesive to non-cohesive sediment was completed between 2007 and 2013. As sediment coarsening, the coastline of the abandoned southern Yellow River sub-delta has remained stable. The significant change in the grain size of the tidal flat surficial sediments may have a profound impact on the future coastal geomorphic evolution.

\section{DATA AVAILABILITY STATEMENT}

The raw data supporting the conclusions of this article will be made available by the authors, without undue reservation.

\section{AUTHOR CONTRIBUTIONS}

QW and XiL designed the research. LZ, CZ, and QW wrote the manuscript, which was edited by all of the co-authors. CZ, XY, and JZ did the fieldwork. XiL, XuL, and XW analyzed the grainsize data. LW and BC refined the interpretations. All authors reviewed the manuscript.

\section{FUNDING}

We were grateful for support from the National Science Foundation of China-Shandong United fund (U1706220), the National Natural Science Foundation of China (41901006 and 41471005), Natural Science Foundation of Shandong Province (ZR2019BD005), and Youth Innovation and Technology Program Team of Shandong University (2020KJH002).
Chang, T. S., Flemming, B. W., and Bartholomä, A. (2007). Distinction between sortable silts and aggregated particles in muddy intertidal sediments of the East Frisian Wadden Sea, southern North Sea. Sediment. Geol. 202, 453-463. doi: 10.1016/j.sedgeo.2007.03.009

Chen, B., and Huang, H. J. (2014). Study on the suspended sediment concentration and the sediment grain size distribution characteristics in the southwest coastal Laizhou Bay. Mar. Sci. Bull. 33, 436-443.

Chen, J. Y. (1980). Coastal Landform, Chinese Editorial Committee of Physical Geography, Chinese Physical Geography (Landform). Beijing: Science Press.

Chen, J. Y. (1982). The historical changes of Bohai Gulf coast. Chinese Editorial Committee of Physical Geography, Chinese Physical Geography (Historical Physical Geography). Beijing: Science Press.

Chu, Z. X., Sun, X. G., Zhai, S. K., and Xu, K. H. (2006). Changing pattern of accretion/ erosion of the modern Yellow River (Yellow) subaerial delta, China: based on remote sensing images. Mar. Geol. 227, 13-30. doi: 10.1016/j.margeo. 2005.11.013

Clarke, D. W., Boyle, J. F., Chiverrell, R. C., Lario, J., and Plater, A. J. (2014). A sediment record of barrier estuary behaviour at the mesoscale: interpreting high-resolution particle size analysis. Geomorphology 221, 51-68. doi: 10.1016/ j.geomorph.2014.05.029

Collins, M. (1987). Sediment transport in the bristol channel: a review. Proc. Geol. Assoc. 98, 367-383. doi: 10.1016/s0016-7878(87)80076-7 
Cui, B. L., and Li, X. Y. (2011). Coastline change of the Yellow River estuary and its response to the sediment and runoff (1976-2005). Geomorphology 127, 32-40. doi: 10.1016/j.geomorph.2010.12.001

Dai, Z., Mei, X., Darby, S. E., Lou, Y., and Li, W. (2018). Fluvial sediment transfer in the Changjiang (Yangtze) river-estuary depositional system. J. Hydrol. 566, 719-734. doi: 10.1016/j.jhydrol.2018.09.019

Dyer, K. R. (1986). Coastal and Estuarine Sediment Dynamics. Chichester: Wiley.

Eisma, D. (1998). Intertidal Deposits: River Mouths, Tidal Flats and Coastal Lagoons. New York, NY: CRC Press.

Ergin, M., and Bodur, M. N. (1999). Silt/clay fractionation in surficial Marmara sediments: implication for water movement and sediment transport paths in a semi-enclosed and two-layered flow system (northeastern Mediterranean Sea). Geo Mar. Lett. 18, 225-233. doi: 10.1007/s003670050072

Flemming, B. W. (1988). "Process and pattern of sediment mixing in a microtidal coastal lagoon along the west coast of South Africa," in Tide-Influenced Sedimentary Environments and Facies, eds P. L. de Boer, A. van Gelder, and S. D. Nio (Dortmund: D Reidel), 275-288. doi: 10.1007/978-94-015-7762-5_20

Folk, R. J., and Ward, W. C. (1957). Brazos river bar: a study in a significance of grain size parameters. J. Sediment. Res. 27, 3-26. doi: 10.1306/74d70646-2b21$11 \mathrm{~d} 7-8648000102 \mathrm{c} 1865 \mathrm{~d}$

Friedman, G. M. (1961). Distinction between dune, beach and river sands from their textural characteristics. Int. J. Sediment. Res. 31, 514-529.

Gensac, E., Gardel, A., Lesourd, S., and Brutier, L. (2015). Morphodynamic evolution of an intertidal mudflat under the influence of amazon sediment supply-Kourou mud bank, French Guiana, South America. Estuar. Coast. Shelf Sci. 158, 53-62. doi: 10.1016/j.ecss.2015.03.017

Giosan, L., Syvitski, J., Constantinescu, S., and Day, J. (2014). Protect the world's deltas. Nature 516, 31-33. doi: 10.1038/516031a

Guo, Y. S. (1980). Coastal change of the modern Yellow river delta. Mar. Sci. 4, 30-34. (in Chinese).,

Jiang, C., Chen, S. L., Pan, S., Fan, Y. S., and Ji, H. Y. (2018). Geomorphic evolution of the Yellow River delta: quantification of basin-scale natural and anthropogenic impacts. Catena 163, 361-377. doi: 10.1016/j.catena.2017.1 2.041

Jiang, C., Pan, S., and Chen, S. L. (2017). Recent morphological changes of the Yellow River (Huanghe) submerged delta: causes and environmental implications. Geomorphology 293, 93-107. doi: 10.1016/j.geomorph.2017.0 4.036

Johnson, M. A., Kenyon, N. H., Belderson, R. H., and Stride, A. H. (1980). "Sand transport," in Offshore Tidal Sands, Processes and Deposits, ed. A. H. Stride (London: Chapman \& Hall), 58-94.

Jongepier, I., Wang, C., Missiaen, T., Soens, T., and Temmerman, S. (2015). Intertidal landscape response time to dike breaching and stepwise re-embankment: a combined historical and geomorphological study. Geomorphology 236, 64-78. doi: 10.1016/j.geomorph.2015.02. 012

Kenyon, N. H., and Stride, A. H. (1970). The tide-swept continental shelf sediments between the Shetland Isles and France. Sedimentol 14, 159-173. doi: 10.1111/j. 1365-3091.1970.tb00190.x

Law, B. A., Hill, P. S., Milligan, T. G., Curran, K. J., Wiberg, P. L., and Wheatcroft, R. A. (2008). Size sorting of fine-grained sediments during erosion: results from the western Gulf of Lions. Continent. Shelf Res. 28, 1935-1946. doi: 10.1016/j. csr.2007.11.006

Law, B. A., Milligan, T. G., Hill, P. S., Newgard, J., Wheatcroft, R. A., and Wiberg, P. L. (2013). Flocculation on a muddy intertidal flat in Willapa Bay, Washington, Part I: a regional survey of the grain size of surficial sediments. Continent. Shelf Res. 60S, S136-S144.

Leonardi, N., Mei, X., Carnacina, I., and Dai, Z. (2021). Marine sediment sustains the accretion of a mixed fluvial-tidal delta. Mar. Geol. 438:106520. doi: 10.1016/ j.margeo.2021.106520

Li, G. X., Wei, H. L., Han, Y. S., and Cheng, Y. J. (1998a). Sedimentation in the Yellow River delta, part I: flow and suspended sediment structure in the upper distributary and the estuary. Mar. Geol. 149, 93-111. doi: 10.1016/s00253227(98)00031-0

Li, G. X., Wei, H. L., Yue, S. H., Cheng, Y. J., and Han, Y. S. (1998b). Sedimentation in the Yellow River delta, part II : suspended sediment dispersal and deposition on the subaqueous delta. Mar. Geol. 149, 113-131. doi: 10.1016/s0025-3227(98) 00032-2
Li, G. X., Zhuang, K. L., and Wei, H. L. (2000). Sedimentation in the Yellow River delta. Part III. seabed erosion and diapirism in the abandoned subaqueous delta lobe. Mar. Geol. 168, 129-144. doi: 10.1016/s0025-3227(00)00053-0

Li, X., Liu, J. P., Saito, Y., and Nguyen, V. L. (2017). Recent evolution of the Mekong Delta and the impacts of dams. Earth Sci. Rev. 175, 1-17. doi: 10.1016/ j.earscirev.2017.10.008

Li, Y. F., Huang, Y. L., and Li, S. K. (1991). Preliminary analysis of coastal/tidal landform and its sedimentation along the present Yellow river delta. Acta Oceanol. Sinic. 13, 662-671.

Liu, F. Y., and Gao, M. D. (1986). The characteristics and exploitation of the mud bay at the Yellow River estuary. Mar. Sci. 10, 20-23.

Liu, G. T., and Yan, X. X. (1998). Geomorphic surveys and sediment analysis of Xiaoqinghe estuary. J. Waterw. Harb. 3, 33-36.

Liu, G. W., Huang, H. J., Liu, Y. X., Yan, L. W., and Du, T. Q. (2010). Numerical study on characteristics of beach evolution during storm surge periods in west coast of Laizhou Bay. Stud. Mar. Sinic 50, 32-39.

Liu, Y. X., Huang, H. J., Qiu, Z. F., and Fan, J. Y. (2013). Detecting coastline change from satellite images based on beach slope estimation in a tidal flat. Int. J. Appl. Earth Obs. Geoinf. 23, 165-176. doi: 10.1016/j.jag.2012.12.005

Liu, Z. H., Wu, J. X., Yu, Y. J., Li, X. G., and Wang, H. X. (1985). The utilization of grain size material in preliminary analysis of the tidal flat sedimentary environment of the Yellow River delta. J. Shandong Coll. Oceanol. 15, 159-167.

Lv, D. M., and Li, Y. J. (2004). Variability of sediment distribution and analysis of hydrodynamic environment in the Yellow estuary and the mid-south Bohai Sea. J. Ocean Univ. China 34, 133-138.

Ma, Y. Y., and Li, G. X. (2010). Evolution history and trend of the modern Yellow River Delta. Acta Oceanol. Sinic 29, 40-52. doi: 10.1007/s13131-010-0 020-4

Mazzullo, J., Leschak, P., and Prusak, D. (1988). Sources and distribution of late quaternary silt in the surficial sediment of the northeastern continental shelf of the United States. Mar. Geol. 78, 241-254. doi: 10.1016/0025-3227(88)90 $112-0$

Pang, J. Z., and Si, S. T. (1980). Fluvial process of the Yellow River estuary II. Hydrographical character and the region of sediment silting. Oceanol. Limnol. Sinic 11, 296-305.

Pejrup, M. (1988). The Triangular Diagram Used for Classification of Estuarine Sediments: A New Approach. Denmark: Pergamon Press.

Qiao, L. L., Bao, X. W., Wu, D. X., and Wang, X. H. (2008). Numerical study of generation of the tidal shear front of the Yellow River mouth. Continent. Shelf Res. 28, 1782-1790. doi: 10.1016/j.csr.2008.04.007

Qiao, S. Q., Shi, X. F., Saito, Y., Li, X. Y., Yu, Y. G., Bai, Y. Z., et al. (2011). Sedimentary records of natural and artificial Yellow (Yellow River) channel shifts during the Holocene in the southern Bohai Sea. Continent. Shelf Res. 31, 1336-1342. doi: 10.1016/j.csr.2011.05.007

Rahman, R., and Plater, A. J. (2014). Particle-size evidence of estuary evolution: a rapid and diagnostic tool for determining the nature of recent saltmarsh accretion. Geomorphology 213, 139-152. doi: 10.1016/j.geomorph.2014.0 1.004

Sahu, B. K. (1964). Depositional mechanism from the size analysis of clastic sediments. J. Sediment. Res. 34, 73-83.

Saito, Y., Wei, H. L., Zhou, Y. Q., Nishimura, A., Sato, Y., and Yokota, S. (2000). Delta progradation and chenier formation in the Yellow, China. J. Asian Earth Sci. 18, 489-497. doi: 10.1016/s1367-9120(99)00080-2

Stanley, D. J., and Warne, A. G. (1993). Nile delta: recent geological evolution and human impact. Science 260, 628-634. doi: 10.1126/science.260.5108.628

Udden, J. A. (1914). Mechanical composition of clastic sediments. Bull. Geol. Soc. Am. 25, 655-744. doi: 10.1130/gsab-25-655

Van Ledden, M., Van Kesteren, W. G. M., and Winterwerp, J. C. (2004). A conceptual framework for the erosion behavior of sand-mud mixtures. Continent. Shelf Res. 24, 1-11. doi: 10.1016/j.csr.2003.09.002

Wang, H. J., Saito, Y., Zhang, Y., Bi, N., Sun, X. X., and Yang, Z. S. (2011). Recent changes of sediment flux to the western Pacific Ocean from major rivers in East and Southeast Asia. Earth Sci. Rev. 108, 80-100. doi: 10.1016/j.earscirev.2011. 06.003

Wang, H. J., Yang, Z. S., Li, G. X., and Jiang, W. S. (2006). Wave climate modeling on the abandoned Yellow (Yellow River) Delta lobe and related deltaic erosion. J. Coast. Res. 22, 906-918. doi: 10.2112/03-0081.1 
Wang, H. J., Yang, Z. S. H., Li, Y. H., Guo, Z. G., Sun, X. X., and Wang, Y. (2007). Dispersal pattern of suspended sediment in the shear frontal zone off the Yellow (Yellow River) mouth. Continent. Shelf Res. 27, 854-871. doi: 10.1016/j.csr. 2006.12.002

Wei, W., Dai, Z., Mei, X., Gao, S., and Liu, J. P. (2018). Multi-decadal morphosedimentary dynamics of the largest Changjiang estuarine marginal shoal: causes and implications. Land Degrad. Dev. 30, 2048-2063. doi: 10.1002/ldr. 3410

Wentworth, C. K. (1922). A scale of grade and class terms for clastic sediments. J. Geol. 30, 377-392. doi: 10.1086/622910

Wu, G. Q. (1992). The study on dynamic mechanism for formation of muddy sediment at present Yellow River estuary. Coast. Eng. 11, 44-52.

Xing, Y. (2007). Comparative Studies on the Magnetic Properties of Surface Sediments From the Changjiang Estuary and the Huanghe estuary. Ph.D. Dissertation. Zhongshan: East China Normal University, 84-89 (in Chinese).

Yang, Z. S., Ji, Y. J., Bi, N. S., Lei, K., and Wang, H. J. (2011). Sediment transport off the Huanghe (Yellow River) delta and in the adjacent Bohai Sea in winter and seasonal comparison. Estuar. Coast. Shelf Sci. 93, 173-181. doi: 10.1016/j.ecss. 2010.06.005

Yang, S. L., Milliman, J. D., Li, P., and Xu, K. (2011). 50,000 dams later: erosion of the Yangtze River and its delta. Glob. Planet. Chang. 75, 14-20. doi: 10.1016/j. gloplacha.2010.09.006

Yu, Y. G., Shi, X. F., Wang, H. J., Yue, C. K., Chen, S. L., Liu, Y. G., et al. (2013). Effects of dams on water and sediment delivery to the sea by the Huanghe (Yellow River): the special role of water-sediment modulation. Anthropocene 3, 72-82. doi: 10.1016/j.ancene.2014.03.001
Zhang, P., Wu, J. Z., Hu, R. J., and Zhu, L. H. (2014). Distribution of surface sediments and modern sedimentary environment in the southwestern Laizhou Bay. Mar. Geol. Front. 30, 11-17. (in Chinese with English abstract).

Zhou, Z., Coco, G., Wegen, M., Gong, Z., Zhang, C. K., and Tounend, L. (2015). Modeling sorting dynamics of cohesive and non-cohesive sediments on intertidal flats under the effect of tides and wind waves. Continent. Shelf Res. 104, 76-91. doi: 10.1016/j.csr.2015.05.010

Conflict of Interest: The authors declare that the research was conducted in the absence of any commercial or financial relationships that could be construed as a potential conflict of interest.

Publisher's Note: All claims expressed in this article are solely those of the authors and do not necessarily represent those of their affiliated organizations, or those of the publisher, the editors and the reviewers. Any product that may be evaluated in this article, or claim that may be made by its manufacturer, is not guaranteed or endorsed by the publisher.

Copyright (c) 2021 Zeng, Zhan, Wang, Liu, Wang, Li, Wang, Yu, Zhang and Cui. This is an open-access article distributed under the terms of the Creative Commons Attribution License (CC BY). The use, distribution or reproduction in other forums is permitted, provided the original author(s) and the copyright owner(s) are credited and that the original publication in this journal is cited, in accordance with accepted academic practice. No use, distribution or reproduction is permitted which does not comply with these terms. 